\title{
THE HERPETOLOGY OF VIEQUES ISLAND
}

\author{
Chapman Grant, Major, United States Ammy
}

Dr. Leonard Stejneger, 1904, in "The Herpetology of Porto Rico" lists eleven reptiles and amphibians from Vieques, as follows:

\section{Species}

Latest Record

1. Leptodactylus albilabris

1900

2. Eleutherodactylus antillensis_-_..--_-_Stejneger

3. Sphaerodactylus grandisquamis_------Stejneger

1900

4. Anolis cuvieri 1862

5. Anolis cristatellus 1900

6. Anolis stratulus Stejneger

7. Anolis pulchellus "?", C. W. Richmond

8. Ameiva exsul _-__-_-_Reinhardt \& Luetken

9. Mabuya sloanii Riise

10. Typhlops jamaicensis" १९",--_------Reinhardt \& Luetken "Virgin Islands"

11. Alsophis antillensis Boulenger

1863

1894

He lists Anolis pulchellus and Typhlops jamaicensis with a "?". The latter is recorded from the "Virgin Islands". It is clear that he expected both species to be on Vieques, but had no proof in regard to Typhlops.

Karl P. Schmidt, 1928, in the Scientific Survey of Porto Rico and the Virgin Islands lists 10 of the same reptiles and amphibians from Vieques. He apparently took only A. cristatellus, pullchellus and stratuhs, counting on the authority of Stejneger for the remainder. He leaves out Typhlops which Stejneger included only on probability.

The writer made a trip to the Island in 1931, where, with the assistance and hospitality of Mr. S. C. McCall, 6 species were added to the fauna and 1 removed, bringing, the total to 15 .

I found the two Salentia very numerous and noisy.

The first new record, Hemidactylus mabouia, was found around old stone buildings at night. It is discussed elsewhere in this issue. Sphaerodactylus townsendi and $S$. roosevelti occur on the extreme eastern dry tip of the Island. Elsewhere Sphaerodactylus danforthi or a closely allied form occurs under trash or palm leaves. This is a two-color-phase-male form. On Culebra there were no intermediates between the speckled head and red-head males, but on Vieques all integrades were found. The form from Vieques shows constant 
minor differences from Sphaerodactylus danforthi, which I believe to be of specific or sub-specific value. They are discussed in another paper. Searching on the extreme dry eastern tip of the Island, in the almost impenetrable brush, I turned over the remains of a deserted termite nest which had.fallen to the ground. I saw a large, coarsely scaled Sphaerodactylus and grabbed. To my delight, I felt the wriggle in my hand, but upon examination, I found only a part of the tail. A diligent search failed to recover the important part of the specimen. The glimpse I had made me think it was $S$. roosevelti. I turned over a rock nearby and found the hatched shells of large Sphaerodactylus eggs and one partly incubated egg. A month. later, Oct. 28, 1931, the egg hatched into what might well be a female $S$. roosevelti. I made color notes as follows: Bright yellow, brightest at tail. A light yellow stripe starts between eyes and extends to tip of tail, bordered on head by slightly darker edges. Dark greenish yellow stripe, width of eye, extends nearly to end of tail, but at scapular region this line is jet black with a tiny white dot in the center. At sacral region, this line is little darker. Behind eye a light yellow line which is interrupted at ear and recommences behind ear runs well onto the tail. A narrow dark line below the latter. Flanks bright yellow. Tiny tip of tail white. A beautiful creature. $32 \mathrm{~mm}$. long when hatched. Egg $9 \times 7 \mathrm{~mm}$. The following day the colors began to fade and the day thereafter the skin loosened up preparatory to shedding. The adult S. roosevelti does not have any yellow, but it is quite possible that the young may have it. The classification of the above specimen is tentative until young of $S$. roosevelti are taken at the southwest corner of Porto Rico, whence I described the species in this Journal, Vol. XV No. 3, page 203 and plate.

Anolis cristatellus is numerous. The fan has a broader orange band than the Porto Rico form but does not approach the color or width of the Culebra form. ${ }^{1}$ I found the high tail fin in about the same proportion as on Porto Rico. I searched for Anolis stratulus but failed to find any. Anolis pulchellus was not very abundant. I looked for a variant on the dry eastern end of the Island but neither was to be found. I did not find a native who had ever seen Anolis cuvieri.

Ameiva exsul fairly swarms on outlying keys. Schmidt thought it extinct on the main Island where the mongoose abounds, but I saw a few Amieivas on the eastern extremity. I believe it is too dry there for the mongoose. 
Mabuya was not seen or known to the natives.

I have one specimen of Typhlops sp. collected by Mr. S. C. Me Call.

Alsophis antillensis is probably nearly extinct except on outlying keys or possibly the eastern tip of the Island. Some natives report having seen a few snakes within the past several years.

The natives speak of the "culebron", Epicrates as occurring on the off shore keys.

I saw a pet Pseudemys in a cistern. The natives claim they are numerous in the lagoons and are sold on the streets for fifteen eents apiece.

An old eitizen of repute says that after several of the hurricanes, large agglomerations of broken branches and trees have floated over from Porto Rico and that Pseudemys has been found in such situations. Such a phenomenon would require an unusual wind of sufficient duration and intensity to overcome the current running between the two islands. Personally, I believe that Pseudemys and Epicrates are the only forms which might survive such an experience.

The species that I strike from the list is Stejueger's st. grandisquamis or S. macrolepis which Sehmidt later confused with $S$. grandisquamis. See page 43 of this issue for discussion.

The herpetological list of Vieques I believe comprises the following:

\begin{tabular}{|c|c|c|}
\hline $\mathrm{s}_{1 y e c \mathrm{i} e \mathrm{~s}} \quad$ Latest & Reeord & \\
\hline 1. Leptodactylus albilabris.....................Grint & & 1931 \\
\hline 2. Eleutherodactylus antillensis____._._......Grant & & 1931 \\
\hline 3. Homidactylus mabouta" "',--_--_---- Grant & & 1931 \\
\hline 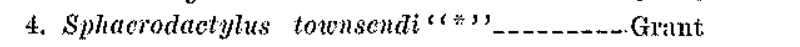 & & 1931 \\
\hline 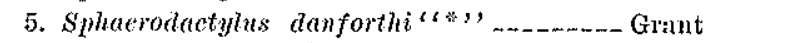 & & 1931 \\
\hline 6. Sphaerodactylus roosevelti "*", & & 1931 \\
\hline 7. Anolis eristatcllus..... & & 1931 \\
\hline 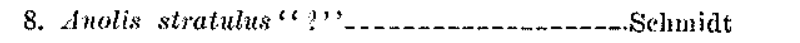 & & 1928 \\
\hline 9. Anolis pulchellus........ Grant & & 1931 \\
\hline 10. Anolis cuvieri" "?", & Luthen & 1862 \\
\hline 11. Ameiva cesul _- & & 1931 \\
\hline 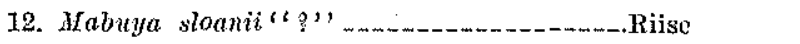 & & 1863 \\
\hline 13. Typhlops, $s p . " r *$, & & 1931 \\
\hline 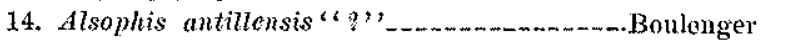 & & 1894 \\
\hline 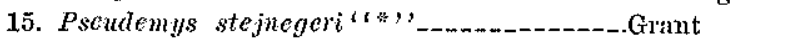 & & 1931 \\
\hline
\end{tabular}

Nons: 1. See p. 220 Vol. XV No. 3 of this Journal.

The "?" denotes species not collected by the writer.

The "w." denotes species added by the writer, 